\title{
COMPETITIVE ASSESSMENT FACTORS OF SEAFOOD EXPORTERS IN VIETNAM
}

\author{
Ai Tran Huu \\ Van Hien University, Ho Chi Minh City, Vietnam
}

This study aims at exploring the factors influencing the competitiveness of seafood export enterprises in Vietnam by surveying 356 people who are leaders and managers of seafood export enterprises in Vietnam. The results for the impact factor analysis with 11 measures proves that these factors should be displayed in the following order of importance: (1) Managerial and operational abilities; (2) Prices; (3) Human resources; (4) Marketing; (5) The power of brand, (6) Distribution channel, (7) Production technology, (8) Finance, (9) Investments in research and development, (10) Being creative, (11) Commercial disputes' resolution. After the analysis the author proposes some recommendations to the management board of seafood export enterprises so that to improve their competitive position.

Keywords: influence factor, competitiveness, exporters, seafood, Vietnam.

\section{Introduction}

Vietnam, with its dense system of rivers and a long sea lines, is very convenient for the development of fishing and aquaculture. Vietnam's seafood output has been growing steadily for the recent 17 years with an average increase of $9.07 \%$ per year. Having quite significant governmental support, the aquaculture has made great progress; the output has been continuously increasing in the recent years, on average, by $12.77 \%$ per year, thus significantly contributing to the growth of seafood production in the country.

A fishery is one of the strongest and most popular industries in Vietnam. It is the leading economic sector of Vietnam, with significant achievements in the past and quite promising future prospects. Assessing the situation as of 2018, despite the world economic market is now only on its way to recovery, high consumption rate is already observable along with quite constant demand for aquatic products. However, the sector is facing many difficulties due to climate changes, inter alia. Technical barriers while importing, strict requirements as to quality standards, regulations on food safety and hygiene are becoming more and more rigid day nearly every day. This especially concerns the imports to the European Union (EU) that withdrew the yellow card for fishery exploitation. If not resolved

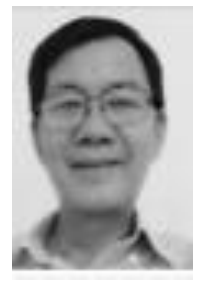

\footnotetext{
Ai Tran Huu

$\mathrm{PhD}$, lecturer of Faculty of Economics, Van Hien University, Ho Chi Minh City, Vietnam

Research interests - markets of agricultural products, SMEs functioning and government support, organic food markets, ecological economics, environmental issues of economic development and corporate social responsibility

Published more than 50 papers in International journals, member of editorial board of International journals

E-mail: aith@vhu.edu.vn
} 


\section{IMPACT OF COMPETITIVE ASSESSMENT FACTORS}

completely, the recommendations made by the EU (in the third quarter of 2017) will greatly affect the turnover and export growth of this industry this year already.

In 2017 was the year when seafood exports reached the highest level ever with $\$ 8.3$ billion, which was almost $\$ 1$ billion more as compared to the level of 2016. Production value and volume increased, thus contributing to the highest position of seafood among agricultural exports in the past year. In 2018, the fisheries sector has set a target - the growth rate of aquaculture value from 5.3\% to 5.8\%. The full yield of aquatic products ranges from 7 mln to $7.5 \mathrm{mln}$ tons. Of which, shrimp farming is 750 thousand tons, the demonstrated growth being $3.6 \%$; catfish production reached $1.3 \mathrm{mln}$ tons, an increase of $3.9 \%$ as compared to 2017 . The sector will continue to bring into play the advantages of shrimp and catfish aquaculture, with the priority given to high-tech aquaculture models aimed at exporting for the amount of 9 bln USD this year.

Competitiveness of the seafood exporters enterprises Ba Ria - Vung Tau is still limited and weak, the ability to survive and strengthen their position at the international market is very low; international integration has forced the seafood exporters enterprises Ba Ria Vung Tau improve their competitiveness, however, the experts in fisheries in Ba Ria - Vung Tau province state that the local seafood exporters need to change the whole old way of working and to accept industrial production on a much larger scale. Enhancing the competitiveness of exported seafood would not only meet the basic needs of the local people in the province, but also provide much more jobs, thus contributing to the implementation of the strategy of boosting export substitution and effective import.

Domestic and international context around the seafood exporters enterprises of Ba Ria - Vung Tau provide both new opportunities and new challenges when it comes to economic integration. To continue growing, the seafood exporters enterprises of Ba Ria - Vung Tau need to improve their competitiveness. Therefore, our study on their competitive capacities aims to identify the factors that influence their consolidation and enhancement.

\section{Literature Review}

\section{Gain a competitive advantage over competition}

Competition at the enterprise level is the struggle between market competitors for customers, for a market share or for specific resources needed for further development of business. However, the essence of today's competition is not destroying competitors, now businesses must create and bring to customers higher value or novelty as opposed to than their competitors (Porter, 1990).

K. Max (1978) once said: "Competition is the rivalry, the fierce struggle between capitalists to seize the favorable conditions in the production and consumption of goods to gain super powers". P. Samuelson (2000) defined it differently already: "Competition is the scramble for market to sell products among entrepreneurs". According to the definition given by A. Lobe (1980), competition is the effort of two or more people to achieve the same goal through certain behaviors and capacities.

In Michael Porter's (1990) view, the company focuses on two goals of growth and product diversification, which do not guarantee actually long-term success for the business. It is important for any business organization to have a sustainable competitive advantage.

According to the OECD (2002), competitiveness is defined as productivity generating high incomes based on the use of effective production factors. It makes businesses, 
industries, localities, countries and regions development in a sustainable way under the conditions of international competition.

Product-level competitiveness is defined as the ability of a product to maintain its longterm position at the competitive market (United Nations, 2001). Company's competing capability is measured by the ability to maintain and expand market share so that to gain profit within both domestic and foreign markets. In the context of a specific sector, competitiveness is the ability to achieve sustainable business performance in the industry over foreign counterparts without protection or subsidies (Blunck, 2006).

According to the World Economic Forum (2006), national level competing capability is judged by nine factors, including: institutions, infrastructure, market efficiency, macroeconomic education and basic education, training and higher education, business qualifications, technological readiness, innovation and creativity.

\section{Factors affecting the competitiveness of enterprises}

There are many internal factors affecting the competitiveness of enterprises, in this paper the author would like to concentrate on the following internal factors:

Internal environmental factors affect business capacities in part of management and operations as the ability to organize and manage enterprises. This is a decisive factor for the existence and development of enterprises in general and their competitiveness level in particular. According to M. Porter, managerial competence can be understood as the pace of human change over general change (Porter, 1980). An enterprise with good price competitiveness is an enterprise that knows its operations, knows how to organize its business well, and minimizes costs, so the selling price of its products and services is lower but still profitable. Competitive advantage depends on the ability to develop in-house knowledge and exploit external knowledge effectively so that to develop skills and creativity within an enterprise (Fabrizio, 2009).

In M. Porter's (1990) view, financial ability is the ability to conduct financial management, risk management of capital and timely mobilize the needed capital so that to meet the demand for materials, labor, equipment procurement, technological innovations and market development. The ability of business marketing is demonstrated by continuous monitoring and responding to market changes, including those revealed by customers, competitors and the macroenvironment overall (Homburg, Grozdanovic \& Klarmann, 2007).

Research and development play an important role in discovering and applying new technologies in a timely manner so that to gain competitive advantages at the market, develop new products ahead of competitors, and improve product quality and production processes to reduce costs. Appropriate technology allows shortening the production time, reducing the energy consumption, increase productivity, lower production costs, improve product quality, to the degree of automation of enterprises, technology friendly School is the trend, and create competitive advantage for the business.

In the process of integration, enterprises are always faced with commercial disputes (contract of carriage, insurance, claims of dumping, tax complaints, food safety and hygiene issues etc.). The consequence of trade disputes is the risk that businesses may be shrinking. Effective distribution of goods is supposed to cover the costs of all involved production processes. In contrast, inefficient distribution of goods will lead to business bottlenecks and may not be able to cover the costs, thus causing bankruptcy. Therefore, the capacity of the distribution channel has become an important competitive tool in the long run as it becomes 


\section{IMPACT OF COMPETITIVE ASSESSMENT FACTORS}

part of company's assets. The market itself is a very important business environment for the company.

\section{External environmental factors affecting business competitiveness}

External factors affecting enterprises' competitiveness are the factors beyond enterprises' control, such as politics, law, government policies, and consumption habits. The role of the state here is to provide an appropriate legal framework and facilitate businesses to compete on an equal footing. However, competition also lowers the profitability of businesses. The market is the place where products are sold, while inputs are sought through buying and selling of goods and services. Laws and policies are very important factors here since they are covering many issues related to enterprises' operations in general and their competitiveness in particular. Business support services such as supplying raw materials, transport services, electricity supply, water supply etc. - all will benefit from the business improving its competitiveness.

\section{Theoretical Models And Hypotheses}

Basing on the studies by Michael Porter (1990), Arthur A. Thompson, Jr. \& A. Strickland (2001), Mohammad Yusuf (2013), Muhammad Yusuf and Torbjørn Trondsen, (2014), the author proposes a research model that includes 11 internal environmental factors and 3 external environmental factors, all affecting the competitiveness of the fisheries sector.

\section{Theoretical Hypotheses}

H1: Market itself has a positive relationship with the competitiveness of Baria-Vungtau seafood enterprises

H1a: The ability to manage and operate has a positive relationship with market factors.

H1b: Marketing has a positive relationship with market factors.

H1c: Prices have a positive relationship with market factors.

H1d: The power of brands has a positive relationship with market factors.

H1e: Human resource has a positive relationship with market factors.

H2: Legal and policy factors have a positive relationship with the competitiveness of Baria-Vungtau seafood enterprises

H2a: Financial capacity has a positive relationship with legal and policy factors. factors.

$\mathrm{H} 2 \mathrm{~b}$ : Production technology has a positive relationship with the legal and policy

H2c: Commercial disputes' resolution has a positive relationship with legal and policy factors.

H3: Infrastructure and support services have a positive relationship with the competitiveness of Baria-Vungtau seafood enterprises

H3a: Distribution channels' capacity has a positive relationship with infrastructure and support services

H3b: Creativity has a positive relationship with the infrastructure and support services.

$\mathrm{H} 3 \mathrm{c}$ : Investment in research and development has a positive relationship with infrastructure and support services. 
Table 1. Factors in the proposed model (compiled by the author)

\begin{tabular}{|c|c|}
\hline Components of the scale & Authors suggesting/mentioning them \\
\hline \multicolumn{2}{|l|}{ Internal environmental factors } \\
\hline The ability to manage and operate & Porter (1990), Thompson-Strickland \\
\hline (2) prices & Porter (1990), Thompson-Strickland \\
\hline (3) human resource & $\begin{array}{l}\text { Thompson-Strickland (2001), Hoang Tran The } \\
\text { (2011), Nha Huynh Thanh et al. (2015) }\end{array}$ \\
\hline (4) marketing & $\begin{array}{l}\text { Thompson-Strickland (2001), Hoang } \text { Tran } \\
\text { (2011), Huynh Thanh Nha et al. (2015) }\end{array}$ \\
\hline (5) the power of brand & $\begin{array}{lllll}\text { Thompson-Strickland } & \text { (2001), Hoang } & \text { Tran } & \text { The } \\
\text { (2011), Porter (1990) } & & & & \\
\end{array}$ \\
\hline $\begin{array}{l}\text { (6) distribution channel (network } \\
\text { efficiency) }\end{array}$ & Thanh Nguyen Vinh (2005) \\
\hline (7) production technology & $\begin{array}{lllll}\text { Thompson-Strickland (2001), Hoang } & \text { Tran } & \text { The } \\
\text { (2011), Quy Pham Thi (2005) } & & & \\
\end{array}$ \\
\hline (8) financial capacity & $\begin{array}{l}\text { Thompson-Strickland (2001), HoangTran The (2011), } \\
\text { Nha Huynh Thanh et al. (2015) }\end{array}$ \\
\hline $\begin{array}{l}\text { (9) investment in research and } \\
\text { development }\end{array}$ & Porter (1990), Thompson-Strickland (2001) \\
\hline $\begin{array}{l}\text { (10) creative ability (creating new and } \\
\text { unique products) }\end{array}$ & $\begin{array}{l}\text { Quy Pham Thi (2005), Muhammad Yusuf et al. } \\
\text { (2014) }\end{array}$ \\
\hline (11) commercial dispute resolution & Thompson-Strickland (2001), HoangTran The (2011), \\
\hline \multicolumn{2}{|l|}{ External environmental factors } \\
\hline (1) Market factors & HoangTran The (2011) \\
\hline (2) Law and Policy Factors & HoangTran The (2011) \\
\hline 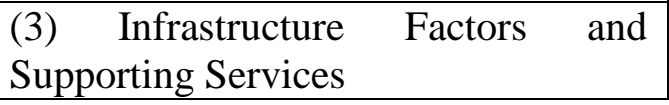 & $\begin{array}{l}\text { HoangTran The (2011), Muhammad Yusuf et al. } \\
\text { (2014), Nghi Nguyen Quoc (2012) }\end{array}$ \\
\hline \multicolumn{2}{|l|}{ The dependent variable } \\
\hline $\begin{array}{l}\text { Competitiveness of the fisheries } \\
\text { sector }\end{array}$ & \\
\hline
\end{tabular}

\section{Methodology}

\section{Procedure for data collection}

Quantitative research has been conducted in Ba Ria - Vung Tau province from March to October 2017. 450 questionnaires were initially distributed, and 408 were received back. After removing 52 invalid questionnaires (21 questionnaires were missing data, 12 questionnaires had more than 1 answer for the same question; 19 questionnaires contained the same evaluation for most of the questions). Thus, 356 questionnaires were used for analysis and verification, reaching the $87.25 \%$ level of acceptance. The main information on the sample is shown in Table 2, in which we can see that the sample meets the quantitative 


\section{IMPACT OF COMPETITIVE ASSESSMENT FACTORS}

and structural criteria as defined by the sample design. The values of the measured variables have the Skewness symmetry coefficient and the Kurtosis concentration coefficient distributed in the range $[-1,+1]$, thus, the distribution can be treated as near normal distribution. It is therefore suitable for applying ML to estimate the parameter numbers in CFA, SEM and other quantitative techniques.

Table 2. Basic information on the surveyed enterprises (compiled by the author)

\begin{tabular}{|c|c|c|c|}
\hline Features & Frequency & Percentage & $\begin{array}{c}\text { Accumulated } \\
\text { percentage }\end{array}$ \\
\hline Joint stock companies with state capital & 14 & 18.40 & 18.40 \\
\hline Private enterprises & 62 & 81.60 & 100.00 \\
\hline Total & 76 & 100.00 & \\
\hline \multicolumn{2}{|c|}{} \\
\hline Enterprises with >500 workers & 282 & 79.20 & 79.20 \\
\hline Enterprises with <500 workers & 74 & 20,80 & 100.00 \\
\hline Total & 356 & 100.00 & \\
\hline
\end{tabular}

\section{Data screening and analysis}

Quantitative research methods have been used in this study. Theoretical model has 14 independent variables measured by 66 observed variables and one dependent variable measured by 3 observed variables. To ensure the questionnaires' content and design would be unambiguously understood by all the respondents, it was preliminary reviewed by 14 experts. To ensure the relevance, the survey questionnaire was piloted with 15 middle managers from the leading seafood enterprises for the purpose of adjusting terms and meanings so that they were easy to understand. The 5-point Likert scale was used in this research with the following levels: Very weak - Weak - Moderate - Strong - Very strong. The steps in structural equation modeling (SEM) analysis by AMOS 22.0 included: CFA analysis, measurement, analysis, discriminant analysis, composite reliability analysis and direct impact analysis, testing the fit of the hypothesized structural model, revised model, (Sentosa et al., 2012).

\section{Results of the Confirmatory Factor Analysis (CFA)}

The CFA results show that all normalized estimates for the factor load factor are high. The criteria for assessing compliance with the survey data are quite high, respectively, Chisquare $=1509,487, \mathrm{df}=776 ; \mathrm{p}=0.008 ;$ Chi square $/ \mathrm{df}=1.945 ; \mathrm{GFI}=0.903 ; \mathrm{TLI}=0.900$; 
CFI $=0.915 ;$ RMSEA $=0.052$. Thus, this is the evidence of the multidirectionality, convergence value and relevance of the market factor scale.

\section{Results of the Structural Equation Model (SEM)}

The SEM has been developed to explore the relationship between market structure (MF), legal and policy factors (LDF), infrastructure and services (IFSS) and the competitiveness of the fisheries sector (CPFS).

The results show that the final calibration model has the statistically significant chisquare being 1525.492 with 826 degrees of freedom $(\mathrm{P}=0.000)$, the relative degree of freedom of the mean square of Cmin /df $1.847(<2)$. Other indicators are: GFI $=0.844(<0.9)$, $\mathrm{TLI}=0.909(>0.9), \mathrm{CFI}=0.921(>0.9)$ and RMSEA $=0.049(<0.08)$. Therefore, this model has achieved compatibility with the data collected. The study model explains $58.49 \%$ (Squared Multiple Correlations) variance of the data.

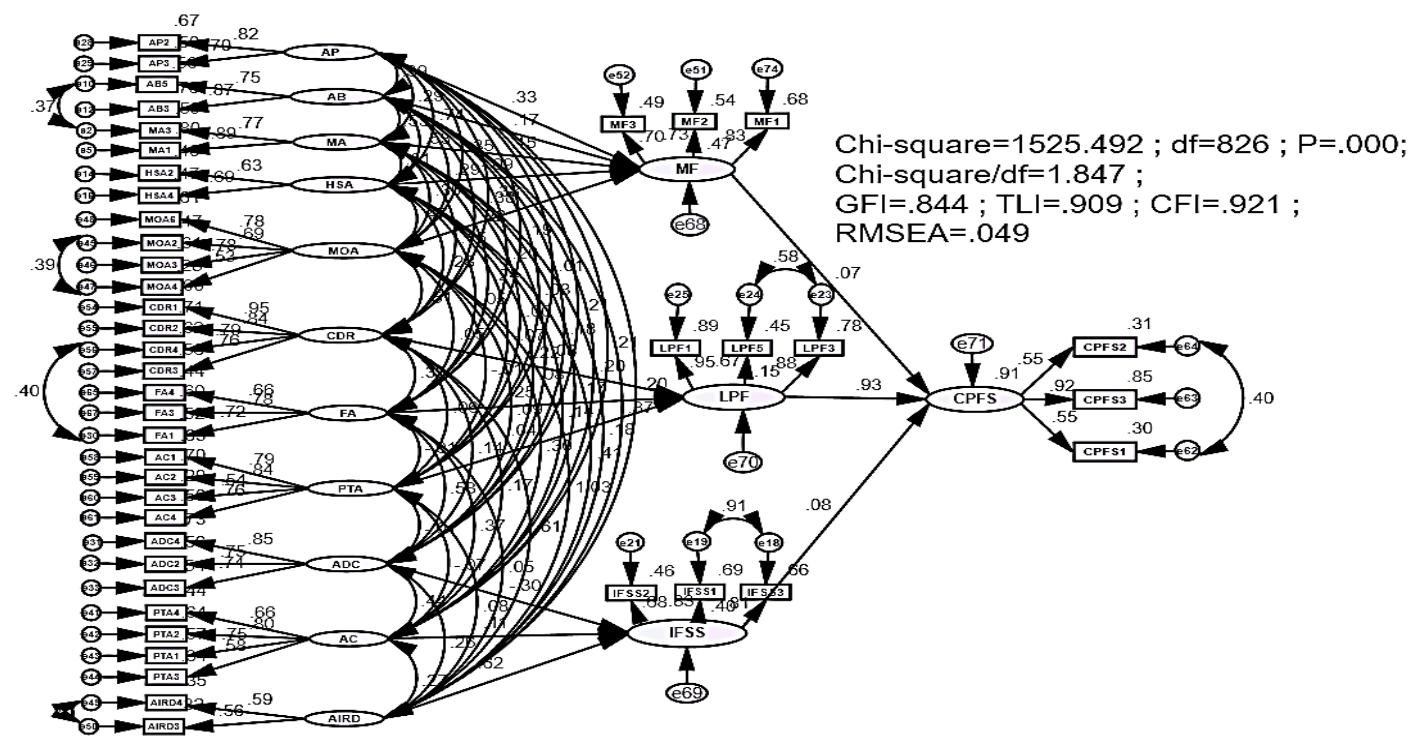

Figure 1. The final version of SEM

(constructed by the author)

The results of estimating the weights are presented in Table 3. Eight components in the theoretical model represent the internal factors impacting enterprise competitiveness:

(1) The ability to manage and operate (MOA),

(2) Prices (AP),

(3) Marketing (MA),

(4) The power of brand (AB),

(5) Distribution channel (CDC),

(6) Financial ability (FA),

(7) Investment in research and development (AIRD),

(8) Commercial dispute resolution (CDR). 


\section{IMPACT OF COMPETITIVE ASSESSMENT FACTORS}

These components are statistically significant $(\mathrm{p} \leq 0,05)$. The rest of the obtained factors include: Production technology (PTA) $(p=0.452)$; Creativity $(A C),(p=0.209)$; Human resource (HSA), $(\mathrm{p}=0.516)$, all three components aren't statistically significant $(\mathrm{P}>0.05)$.

Our results show that enterprises have not paid adequate attention to these features, which may be due to the lack of knowledge or lack of managerial capacities. Most of the enterprises in question also lack capital so that to expand their market share, others have no specific strategy to penetrate new markets, in many cases human resources are lacking or are underqualified.

Table 2. Estimation results for the relationships between the factors of competitiveness (calculated by the author)

\begin{tabular}{|ccc|cccc|}
\hline & Relation & & Estimate & S.E. & C.R. & P \\
\hline MF & $<---$ & MA & .155 & .073 & 2.131 & .033 \\
MF & $<---$ & AB & .133 & .066 & 2.010 & .044 \\
MF & $<---$ & HSA & -.099 & .152 & -.650 & .516 \\
MF & $<---$ & AP & .282 & .095 & 2.973 & .003 \\
IFSS & $<---$ & ADC & .215 & .062 & -3.476 & $* * *$ \\
IFSS & $<---$ & AC & .106 & .084 & 1.256 & .209 \\
LPF & $<---$ & CDR & .216 & .055 & 3.902 & $* * *$ \\
LPF & $<---$ & PTA & .030 & .040 & .751 & .452 \\
LPF & $<---$ & FA & .289 & .071 & 4.037 & $* * *$ \\
MF & $<---$ & MOA & .425 & .081 & 5.264 & $* * *$ \\
IFSS & $<---$ & AIRD & 1.016 & .124 & 8.172 & $* * *$ \\
CPFS & $<---$ & MF & .052 & .026 & 2.041 & .041 \\
CPFS & $<---$ & LPF & .508 & .047 & 10.797 & $* * *$ \\
CPFS & $<---$ & IFSS & .048 & .023 & 2.131 & .033 \\
\hline
\end{tabular}

\section{Conclusion}

The results show that there are 11 factors directly related to the competitiveness of the fisheries sector, all having a positive and significant impact, therefore, the hypotheses H1a, $\mathrm{H} 1 \mathrm{~b}, \mathrm{H} 1 \mathrm{c} \mathrm{H} 1 \mathrm{~d}, \mathrm{H} 2 \mathrm{~b}, \mathrm{H} 2 \mathrm{c}, \mathrm{H} 3 \mathrm{a}, \mathrm{H} 3 \mathrm{c}, \mathrm{H} 1, \mathrm{H} 2, \mathrm{H} 3$ are accepted with $\mathrm{P}<0.05$. More specifically:

(1) Investments in $R \& D$ with $\beta=1.016$ ( $p=0.000<0.05)$ are strongly influenced by international cooperation in the field of sciences and research, thus more science transfers should be encouraged so that to raise the scientifically grounded level of production for the major aquatic products.

(2) Law and Policy Factors with $\beta=0.508(p=0.000<0.05)$ have the strongest effect. State policies should be designed to support the competitiveness of the fishery industry. 
(3) Management and operations with $\beta=0.425(\mathrm{p}=0.000<0.05)$ have quite strong influence on seafood export competitiveness. High value of this factor shows that a new type of business knowledgeable market is being formed nowadays.

(4) Financial ability with $\beta=0.289(\mathrm{p}=0.000<0.05)$ means that the state should expand its pilot lending program so that to apply it gradually nationwide.

(5) Prices have their strong influence with $\beta=0.282(\mathrm{p}=0.003<0.05)$. This suggests that the selling price of fish and shrimp in Vietnam has a positive effect on the volumes of long-term and short-term export of fish and shrimp. This factor is quite able to increase the competitiveness of the fishery sector overall and even remove the barriers in taxation imposed recently on the seafood being exported to the US market.

(6) Commercial disputes resolution with $\beta=0.216(p=0.050<0.05)$ shows that more and more commercial disputes may appear in the near future already. A flexible dispute resolution mechanism in line with international practices and practical needs of Vietnam becomes a real must for the local fisheries.

(7) Distribution channel with $\beta=0.215(\mathrm{p}=0.000<0.05)$ also strongly influences the seafood exporters and their trade promotion methods especially.

(8) Marketing got $\beta=0.155(\mathrm{p}=0.033<0.05)$. This shows that exporters are getting more and more interested in marketing mix these days.

(9) The power of brands with $\beta=0.133$ ( $\mathrm{p}=0.044<0.05)$ shows that brand development is an urgent issue, especially in the context of deepening integration of Vietnamese economy into the world economy.

(10) Market overall with $\beta=0.052(\mathrm{p}=0.044<0.05)$ impacts seafood exports as well, and it would be fair to assume that quality is the key impact factor here.

(11) Infrastructure and supporting services with $\beta=0.048(\mathrm{p}=0.033<0.05)$ are also significant factors affecting fisheries' export competitiveness. Logistics is the bridge in the processes of exchanging goods and circulating products.

There are three other factors that have been found to be not statistically significant $(\mathrm{P}>$ 0.05). Namely:

(1) Creativity with $\beta=0.052(\mathrm{p}=0.209>0.05)$. This is yet another proof that fisheries in Vietnam mostly ignore the latest achievements of sciences and technologies, thus, leaving very little space (if any) for the potential introduction of innovations.

(2) Human resource with $\beta=-0.099(p=0.516>0.05)$. This is consistent with many other recent surveys and other studies, also showing that majority of factories, farms and fisheries in Vietnam have more than $60 \%$ of workers without any technical expertise.

(3) Production technology with $\beta=-0.03$ ( $p=0.452>0.05)$ shows that enterprises are not interested in introduction of latest technologies because they do not understand the importance of these capabilities for further development of their businesses. 


\section{IMPACT OF COMPETITIVE ASSESSMENT FACTORS}

\section{Implications}

\section{General planning solutions}

Planning should be more specifically concentrated on the selected industrial aquacultures. Planning concerning the development of shrimp, catfish, tuna and mollusk areas should be reviewed. Planning on aquatic products' processing should be introduced. Detailed planning should be offered for the largest fisheries located on the coastline.

\section{Solutions in the field of science and technology}

Assessment of the fisheries' resources should become annual. Post-harvest preservation technologies should be more actively transferred directly to the ocean tuna fishing vessels. Fisheries' management practices should be made more compliant with the EU rules and regulations. More research on nutrition and aquatic feed should be encouraged so that to develop disease-free aquatic species. More attention and funds should be directed into research and surveillance of aquatic animal diseases. Biosafety and marine environmental protection should become one of the top priorities for both researchers and state authorities.

\section{Investment, credit and other financial solutions}

Investing in the following projects seems to be of top priority as of today: Infrastructure of big fisheries centers; intensive farming areas for giant tiger shrimp, white shrimp and catfish; fisheries management information system; environmental warning systems and aquaculture inspection. Another important direction would be providing preferential crediting for the development of fisheries production and trading.

\section{Solutions related to management and operations}

Many legal documents, strategies and plans need to be urgently reviewed for the purposes of compliance to the principles of responsible fisheries management. Regulations on the conditions of breeding and aquaculture establishments also need to be reviewed in detail, and this refers to all legal documents on both domestic production and export of aquatic products. Same applies to the regulations on quality standards for all aquatic products, standards of supplies, chemicals and quality of aquatic feeds.

\section{Trade promotion programs and new market solutions}

It would be appropriate to introduce and develop the networks of trading agents at the most important markets: the USA, the EU, and Japan. Establishing a market information system dedicated to aquatic products specifically (inside and outside the country) would be also appropriate as well as formulating a more exact guidance on management of wholesale fish markets and auctioning fishery products at fishing ports. Specific branding campaigns would be helpful for each key product. 


\section{Summary}

Vietnam's seafood exporters are only growing in number these days. They have already contributed greatly to industrialization and overall modernization of the country. But in the context of global economic integration, this type of business must win in competition at both foreign and domestic markets, and as of today the problem of competition is a huge challenge for all Vietnamese fisheries, thus requiring much greater creativity and initiative from them.

To play their economic role more explicitly, Vietnamese seafood exporters must take advantage of all their strengths, limiting at the same time the negative impact of their weaknesses. On the other hand, the state needs to create a common legal framework and develop all necessary policies for Vietnamese seafood exporters, thus enhancing the competitiveness of Vietnamese seafood exporters. Long-term work is required here from the side of the State, all related businesses and Vietnamese society too.

\section{References:}

Balkytė, A. \& Tvaronavičienè, M. (2010). The inclusion of sustainable development dimension into the competitiveness theory. Available at: http://citeseerx.ist.psu.edu/viewdoc/download?doi=10.1.1.465.1926\&rep=rep1\&type=pdf

Bartlett, A. \& Ghoshal, A. (1989). Managing Across Borders. Harvard Business School Press, Boston, MA.

Black, J. (2009). Scottish Schools Adolescent Lifestyle and Substance Use Survey. National Report. Edinburgh: The Stationery Office.

Buckely, P. (1991). Foreign Market Servicing Strategies and Competitiveness. Journal of General Management, 17(2), 34-46.

Damanpour, F. (1991). Organizational innovation: A Meta-Analysis of effect of Determinants and Moderators. Academy of Management Journal, 34 (3), pp. 555-590.

Destination Competitiveness: Development of a Model with Application to Australia and the Republic of Korea. Australian Govt Report, October. Available at: http://www.ibrarian.net/navon/paper/Destination_Competitiveness_Development_of_a_Mod. pdf?paperid $=1459827$

Dwyer, L. Forsyth, P. \& Rao, P. (2000) The Price Competitiveness of Travel and Tourism: a comparison of 19 Destination. Tourism Management, 21: 9-22.

Edmonds, T. (2000). Regional Competitiveness \& the Role of the Knowledge Economy, House of Commons Library. London: Research Publications Office, 73-55.

Fagerberg, J., Mowery, J. \& Nelson, R. (2003). Innovation and Competitiveness, Oxford University Press.

Hoang, T. (2011). Raising the competitiveness of seafood exporters to 2020. PhD thesis, University of Economics, HCMC

Hoat Phan Minh (2007). Using the Thompson-Strickland method to evaluate the overall competitiveness of enterprises. Institute of Science, Hanoi.

Jay B. (2001). Resource-based theories of competitive advantage: A ten-year retrospective on the resource-based view. Journal of Management, 27: 643-650.

Marx, K. (1978). Karl Marx - Friedrich Engels. The Truth Publisher.

Mehra, S. (1998). Perpetual Analysis and Continuous Improvement: A must for Organizational Competitiveness, The University of Memphis, 24, 1. 


\section{IMPACT OF COMPETITIVE ASSESSMENT FACTORS}

Nghi Nguyen Quoc, Nguyen Dinh Yen Oanh, Phan Van Phung \& Nguyen Bich Ngoc (2012). Analyzing the competitive advantage of seafood processing industry in Can Tho city by Paca method. Proceedings of Science: 38-46. Can Tho University.

Nha Huynh Thanh (2015). Assessing the competitiveness of private enterprises in Can Tho city. Journal of Science, 6 (2): 30 - 36.

OECD (2013). Economic Policy Reforms 2013: Going for Growth. OECD Publishing. http://dx.doi.org/10.1787/growth-2013-en .

Porter, M. (1998). The Competitive Advantage of Nations. Macmillan Business.

Quy Pham Thi (2005). Policies and solutions to improve the competitiveness of Vietnam's fishery exports in the process of international economic integration. Ministry of Science and Technology, Ministry of Science and Technology, pp. 38-80.

Ramasamy, H. (1995) Productivity in the Age of Competitiveness: Focus on Manufacturing in Singapore. APO Monograph Series, 16, Asian Productivity Organisation.

Ricardo, D. (1817). On the Principles of Political Economy and Taxation. Piero Sraffa (Ed.). Works and Correspondence of David Ricardo, Cambridge University Press.

Samuelson, P. (2000). Economics. Educational Publishing House.

Thompson, A. \& Strickland, A. (2001). Crafting and Executing Strategy. Text and Readings, New York McGraw-Hill.

United Nations (2001). Methodology for the assessment of competitiveness of selected existing industries, NY.

US Council on Competitiveness (2001). U.S. Competitiveness 2001: Strengths, Vulnerabilities and Long-Term Priorities, Washington, D.C.

Yang, D. \& Zhang, Q. (2000). Drift-Independent Volatility Estimation Based on High, Low, Open, and Close Prices, Journal of Business, 73, 3.

Yusuf, M. \& Trondsen, T. (2013). A market-oriented innovative quality framework for the investigation of competitive entry opportunities into new seafood markets for producers. International Journal of Quality and Innovation, 2 (2): 175-192.

Paper submitted

Paper accepted for publishing

Paper published online
O6 May 2018

12 June 2018

31 July 2018 